JEPP

3,1

160

Received 28 February 2012

Revised 14 January 2013

Accepted 17 January 2013

\title{
Contingency factors on university spin-off formation: an empirical study in Germany
}

\author{
Arndt Lautenschläger and Heiko Haase \\ Department of Business Administration, \\ Center for Innovation and Entrepreneurship, \\ University of Applied Sciences Jena, Jena, Germany, and \\ Jan Kratzer \\ School of Economics and Management, Center for Entrepreneurship, \\ Berlin University of Technology, Berlin, Germany
}

\begin{abstract}
Purpose - The purpose of this paper is to investigate contingency factors on the emergence of university spin-off firms. The institutional and organisational factors the paper explores comprise the transfer potential of the university, the strategy and characteristics of the University Technology Transfer Organisations and specific support for spin-off formation.

Design/methodology/approach - Based on a unique data set, this cross-sectional study analyses the population of 54 higher education institutions in Germany. At this, 31.4 per cent of the German universities with technology transfer activities participated in this study.

Findings - The research identifies a high degree of heterogeneity in the qualification of University Technology Transfer Offices (UTTO) staff and the existence of an entrepreneurship support programme as important antecedents of spin-off formation. In addition, the results reveal that pursuing different or multiple transfer strategies will not be detrimental to the establishment of spin-offs.

Practical implications - It seems that there is still a lack of consensus with respect to the importance of spin-offs as an effective channel to transform research results into economic value. Furthermore, universities aiming at the promotion of spin-offs need appropriate regulations which do not jeopardise the usage of research outcomes for entrepreneurial purposes.

Originality/value - This study contributes to enhance the knowledge on what promotes and inhibits the formation of university spin-off firms, as it first analyses a considerable population of UTTOs in Germany and explicitly considers underexplored and new contingency factors.

Keywords Germany, Universities, Academic entrepreneurship, Spin-off firms, Technology transfer offices Paper type Research paper
\end{abstract}

\section{Introduction}

New business ventures founded to exploit academic research have become an important economic phenomenon (Markman et al., 2005b). In fact, spin-off firms are increasingly seen as a source of regional economic development. How universities can contribute to economic progress and structural change, especially in their immediate proximity, is illustrated by the examples of the Massachusetts Institute of Technology and other universities (Bramwell and Wolfe, 2008; Chrisman et al., 1995; Hsu et al., 2007). In general, fostering spin-off formation is today at the core of many national and local economic policies (Rasmussen, 2008; Shane, 2004). Consequently, research is needed to better understand how universities can facilitate and enhance the creation of spin-off firms (Markman et al., 2008).

As for definitions, Pirnay et al. (2003) describes academic spin-offs as new firms created to exploit knowledge, technology or research results developed within a

Journal of Entrepreneurship and Public Policy

Vol. 3 No. 1, 2014

pp. 160-176

(C) Emerald Group Publishing Limited 2045-2101

DOI 10.1108/JEPP-02-2012-0013 
university, in which the founders have their origins in the higher education institution. Similarly, Rasmussen and Borch (2010) as well as Rasmussen (2011) speak of a new venture initiated in a university setting, based on technology developed in the academia. Due to their catalysing role in knowledge creation and transfer, spin-offs from universities are one of the most promising channels to transfer research results from academia to industry (Ndonzuau et al., 2002; Pérez Pérez and Martínez Sánchez, 2003). They contribute to a fast and direct implementation of new knowledge into economic value, and, in doing so, they account for the emergence of innovative products and services. Accordingly, the spin-off formation rate is often seen as a key indicator for the quality and performance of technology transfer and of related organisations (Arundel and Bordoy, 2008; OECD, 2002; Rogers et al., 2000).

Aside of being a means of technology transfer and commercialisation, spin-offs are valuable in several aspects: They tend to be located geographically close to the institutions that spawn them, making them valuable entities for regional economic development (Shane, 2004; Zucker et al., 1998). In this regard, spin-offs are capable of enhancing the relationship to the local business community, contribute to economic restructuring and generate employment in innovative branches (Charles, 2003; Pérez Pérez and Martínez Sánchez, 2003). Academic biotechnological breakthroughs and discoveries, for example, are generally transferred into commercial applications by means of university spin-offs (Zucker et al., 2002).

Factors related to the parent organisation that influence university spin-off formation have been the subject of several studies (e.g. Caldera and Debande, 2010; Debackere and Veugelers, 2005; Di Gregorio and Shane, 2003; Lach and Schankerman, 2008; Lockett and Wright, 2005; O'Shea et al., 2005; Powers and McDougall, 2005). In the value creation chain from university to industry, university technology transfer offices (UTTOs) are fundamental (Siegel et al., 2004). As technology intermediaries, UTTOs adopt various configurations and enact different transfer strategies, equally important when determining the level of spin-off activities. However, only a few studies have examined UTTOs in particular (e.g. Caldera and Debande, 2010; Debackere and Veugelers, 2005; Di Gregorio and Shane, 2003; Markman et al., 2005b; Moray and Clarysse, 2005). Nevertheless, the conjunction of both institutional and organisational factors has not yet been sufficiently explored, and some potential antecedents for university spin-off formation still lack scientific scrutiny.

Considering this situation, the objective of this paper is to fill this research caveat. In our analysis of contingency factors, we particularly consider the university's transfer potential, the UTTO's strategies and characteristics as well as specific measures to support spin-offs. Hence, our research question is as follows: which institutional and organisational factors influence the number of spin-offs emanating from a university? To answer this question, we identified and applied a unique sample of UTTOs in Germany.

Up to now, quantitative studies involving a number of universities are mainly focused on the USA (e.g. Di Gregorio and Shane, 2003; Lach and Schankerman, 2008; Markman et al., 2005b; O'Shea et al., 2005; Powers and McDougall, 2005). Nevertheless, there is a growing interest concerning this subject in Europe over the last years (e.g. Caldera and Debande, 2010; Lockett and Wright, 2005; Van Looy et al., 2011). According to our current state of knowledge, there has yet been no study that scrutinises UTTOs and the related framework at German universities in the light of their influence on spin-off formation. Taken as a whole, this study contributes to enhance our knowledge on what promotes and inhibits the formation of university
University spin-off formation

161 
JEPP

3,1

162 spin-off firms, as it first analyses a considerable population of UTTOs in Germany and explicitly considers underexplored and new contingency factors.

The rest of this paper is organised as follows: Section 2 provides the theoretical framework and develops our research hypotheses. Section 3 explains the methodology, i.e. sampling, data collection, variables and statistical analyses. Section 4 highlights and discusses the descriptive and explorative findings. Section 5 presents conclusions, implications as well as limitations of our research.

\section{Theory and hypotheses}

2.1 Theoretical framework

Academic entrepreneurship is embedded in the university context, which both can facilitate and constrain the venturing process (Kenney and Goe, 2004; Rasmussen and Borch, 2010). In this context, institutions are important determinants of spin-off activities. Therefore, the new institutional economics is an appropriate approach for analysing contingency factors that might influence spin-of formation. North (1990, p. 3) defines institutions as "the rules of the game [...] or [...] humanly devised constraints that shape human interaction". North (1994, p. 361) adds "if institutions are the rules of the game, organisations and their entrepreneurs are the players". This demarcation between institutions and organisations allows differentiating the analysis between certain established legal rules and social norms on the one hand, and organisational arrangements such as universities or UTTOs on the other.

Several studies on technology transfer and academic entrepreneurship were anchored in institutional frameworks. For example, Bercovitz and Feldman (2005) investigated the effect of institutional structures and policies on patenting and licensing behaviour. Moray and Clarysse (2005) looked at how institutional changes at the parent organisation influence the resource endowments of science-based ventures. Di Gregorio and Shane (2003) related institutional determinants with the spin-off rate of public research organisations. Similar to these latter scholars, the present paper also considers institutional factors that might have a positive or negative influence on entrepreneurial activities in the academia.

With regard to the organisational endowments, we apply the resource-based perspective (Penrose, 1959; Wernerfelt, 1984). In fact, the resource-based theory fits comfortably within the organisational economics paradigm (Mahoney and Pandian, 1992). It consists of analysing the position of resources in an organisation and looking at some strategic options suggested by that analysis (Wernerfelt, 1984). Also Grant (1991) underpins the relevance of adopting strategies which enable the organisation to make effective use of the resources available. He distinguishes between resources and competences: While resources are the source of capacity, competences are the source of competitive advantages. A growing research stream on university spin-off emergence adopts resource-based perspectives (e.g. Druilhe and Garnsey, 2004; Heirman and Clarysse, 2004; Lockett and Wright, 2005; O'Shea et al., 2005; Powers and McDougall, 2005; Vohora et al., 2004). In this vein, we also included resource-based organisational factors in our analysis.

\subsection{Research hypotheses}

From a resource-based perspective, research indicates that some specific resources hold by a university make the rate of spin-off firms higher. As outputs from access to resources, it has been found that intellectual eminence (Di Gregorio and Shane, 2003), higher R\&D expenditures (Lockett and Wright, 2005) or scientific productivity 
(Van Looy et al., 2011) are positively associated with entrepreneurial effectiveness. These measures stand for a university's transfer potential. In this regard, the transfer potential can also be captured by size, as larger universities are likely to generate more research. In fact, it seems that the size of the university is positively related to the amount of technology transfer (Belenzon and Schankerman, 2009). Size can be measured by the number of researchers and students or budget an academic institution possesses. Hence, the higher the university's human and financial resources, the higher are the possibilities for the emergence of spin-off firms. This assumption was partially confirmed by the study of Caldera and Debande (2010).

Nevertheless, in some cases, size may not always have an influence on the transfer potential. Some smaller universities have their particular strengths in research, along with efficient external support, which may place them in an advantageous position compared to their larger counterparts. Hence, on the other hand, a further indicator of a university's transfer potential is the perceived capability to generate and allocate scientific knowledge. Despite this measure being self-assessed and of subjective nature, it is an operationalisable alternative to capture the phenomenon. Due to their function as academia-industry intermediaries, we believe that in any case UTTOs are most likely to report the transfer potential. Therefore, we hypothesise the following:

H1a. The number of spin-off firms emerging from a university is positively correlated with the university's size measured by the number of researchers.

H1b. The number of spin-off firms emerging from a university is positively correlated with the university's size measured by the number of students.

H1c. The number of spin-off firms emerging from a university is positively correlated with the university's size measured by the university's budget.

H1d. The number of spin-off firms emerging from a university is positively correlated with the UTTO's self-reported transfer potential of the university.

Besides spin-off firms, there is a great variety of channels through which university knowledge and technology and can be transferred. They comprise not only the exchange of codified academic research results in the form of publications, licensing and patents, but also collaborative and contracted research activities as well as student, graduate and researcher mobility, along with meetings and conferences, consultancy, joint supervision of final degree theses and informal contacts (Bekkers and Bodas Freitas, 2008; Cohen et al., 2002; D'Este and Fontana, 2007; D'Este and Patel, 2007; Rynes et al., 2001; Valentín, 2002; Wright et al., 2008).

However, these transfer strategies require different forms of qualitative involvement and levels of commitment on the part of the transferring institution (D'Este and Patel, 2007; Rosenberg and Nelson, 1994). In fact, Markman et al. (2005b) revealed complex relationships between the various UTTO structures and strategies which have an impact on spin-off emergence. More concretely, Van Looy et al. (2011) studied 105 European universities and revealed that contract research and spin-off activities facilitated each other. Crespi et al. (2011) brought to light that the extent of patenting activities is positively correlated with the engagement in other transfer channels, and this again results above all in a linear correlation with setting up academic spin-offs.
University spin-off formation

163 
JEPP

3,1

164

We believe that the number of spin-offs a university establishes is linked to the UTTO's transfer strategy as an important institutional factor. In particular, a focus on strategies such as the transfer of information (consultancy, publications, meetings, conferences, joint supervision), the transfer of people (employment of researchers and graduates, student placements), the transfer by joint (collaborative and contracted) research and the transfer by patents might also foster the emergence of spin-offs. These reflections lead us to formulate our second set of hypotheses:

H2a. The number of spin-off firms emerging from a university is positively correlated with the UTTO's focus on the transfer of information.

$H 2 b$. The number of spin-off firms emerging from a university is positively correlated with the UTTO's focus on the transfer of people.

H2c. The number of spin-off firms emerging from a university is positively correlated with the UTTO's focus on the transfer by joint research.

H2d. The number of spin-off firms emerging from a university is positively correlated with the UTTO's focus on the transfer by patents.

H2e. The number of spin-off firms emerging from a university is positively correlated with the UTTO's focus on the transfer by spin-offs.

Furthermore, it is assumed that some particular UTTO characteristics impact the emergence of spin-offs. On an institutional level, several researchers found out that a clear-stated mission and explicitly formulated objectives will have a positive impact on the success of the technology transfer efforts of universities and their UTTOs (Friedman and Silberman, 2003; Mowery et al., 2004). Likewise, Caldera and Debande (2010) revealed that universities with established policies and procedures for the management of technology transfer perform better, even in terms of the number of spin-offs created.

From an organisational, by means resource-based perspective, Siegel et al. (2004) underpins that staffing is a critical aspect for the effectiveness of the technology transfer process. In an exhaustive study among Spanish universities, Caldera and Debande (2010) discovered that the size of the UTTO positively affects the spin-off activities. O'Shea et al. (2005) found that more resources invested in UTTO personnel make a university more likely to have a high spin-off rate. This pertains, in our view, not only to the mere number of UTTO employees, but rather to their qualifications and heterogeneity in hard and soft competences. As spin-off support requires a variety of competencies and skills, we think that particularly the heterogeneity in qualification of UTTO employees will result beneficial and include this variable in our analysis as new potential contingency factor.

In transferring university knowledge and technology, the participation of researchers and faculty-inventors in the commercialisation process seems to be another critical institutional determinant of success. Jensen and Thursby (2001) as well as Thursby and Thursby (2002) found that most science-based technologies are quite embryonic and require additional development. Hence, due to their implicit knowledge, the active involvement and cooperation with the researchers and inventors is widely considered as 
essential for a reasonable chance of commercial success (Jensen and Thursby, 2001; Markman et al., 2005a, b; Thursby and Thursby, 2002). Viewed in this light, we deduct the following hypotheses:

H3a. The number of spin-off firms emerging from a university is positively correlated with the existence of an explicit mission for technology transfer (patent policy).

$H 3 b$. The number of spin-off firms emerging from a university is positively correlated with the number of UTTO employees.

H3c. The number of spin-off firms emerging from a university is positively correlated with the heterogeneity in qualification of UTTO employees.

H3d. The number of spin-off firms emerging from a university is positively correlated with the involvement of the researchers/inventors in the commercialisation process.

With a resource-based view, many governments now provide the universities with external funding and support for spin-off creation. From a fiscal perspective, measuring the effect of these programmes is an important task. In their research in Spain, Caldera and Debande (2010) included the existence of university spin-off programmes as a parameter and detected positive effects. In Germany, the German Federal Ministries of Education and of Economics have launched a series of measures within the so-called EXIST programme (Kulicke, 2006). Since 1998, the EXIST programme lines promise universities support in building up an entrepreneurial infrastructure, provide grants to business start-ups and promote the transfer of research outcomes by spin-offs. In most cases, the UTTOs are directly engaged in these activities. Knowledge on a potential relationship between the EXIST programme and spin-off rate will help to evaluate the effectiveness of such public funding.

Beyond this, the university's commitment itself to new venture creation and to support entrepreneurship-related initiatives and infrastructure is expected to influence the occurrence of spin-offs. In this vein, establishing professorships in entrepreneurship has nowadays transformed into a global phenomenon. Its development emanated from Anglo-Saxon regions, especially the USA as the pace setting country in this field (Katz, 2003). In 1998, the first Chair in Entrepreneurship was created in Germany, and after that the number grew considerably. At present, the periodically conducted FGF survey on entrepreneurship professorships revealed 102 endowed positions, which have their focus on entrepreneurship-related research, education and transfer (FGF, 2012). It is likely that existence of a professorship in entrepreneurship implies positive effects on spin-off formation. Consequently, we draw up our last set of hypotheses:

H4a. The number of spin-off firms emerging from a university is positively correlated with the support received from the EXIST programme.

H4b. The number of spin-off firms emerging from a university is positively correlated with the existence of a professorship in entrepreneurship at the university.
University spin-off formation

165 
JEPP
3,1

166

\section{Methodology}

\subsection{Sampling and data collection}

To test the hypotheses, we performed an empirical study, aiming at a whole-population survey of German higher education institutions being actively engaged in technology transfer. Therefore, in a first step we built up a complete database of German universities, based on publicly available data from the Association of Universities and other Higher Education Institutions in Germany (www.hrk.de). In a second step, by individually researching the university web sites, we identified the UTTOs and the respective contact persons. As we focus on technology transfer, we excluded those higher education institutions with explicit humanistic, pedagogic or musical orientation. As a result, we obtained a source list composed of 172 universities.

After a pre-test of four UTTOs, the survey was conducted from December 2009 to April 2010. The UTTOs' directors were approached by e-mail and were provided with an anonymous personalised link to a comprehensive and standardised online questionnaire. The final questionnaire was made up of various groups of questions related to the transfer potential of the university (number of students and researchers, budget as well as self-reported transfer potential), to the UTTO's transfer activities (preferred transfer strategies, number of spin-off firms) and to the UTTO's institutional and organisational characteristics (explicit mission, number of employees and their qualification, researcher/inventor involvement). The existence of a professorship in entrepreneurship was reconciled with the FGF (2012), and the support received from the EXIST programme was aligned with Kulicke (2006).

After sending out one reminder, we received answers from 67 UTTOs, and 54 of them provided information on the number of spin-off firms established in the year 2008. These 54 UTTOs make up our final sample for which we are able to conduct the analysis, being equivalent to 31.4 per cent response rate. In other words, almost a third of those German higher education institutions with technology transfer activities participated in this study.

\subsection{Variables}

Dependent variable. As this paper focuses on the explanation of the emergence of spin-off firms from higher education institutions, the respective number reported by the UTTO is treated as the dependent variable, being numeric in nature.

Independent variables. We used numeric data such as the number of researchers, number of students as well as the financial budgets of the universities. The number of UTTO employees and their qualifications were determined for the following six categories: natural sciences, engineering, business management, law, administrative and others. The self-reported transfer potential, the importance of the five main transfer strategies (transfer of information, of people, by joint research, by patents and by spin-offs) and the involvement of researchers/inventors were measured through seven-point Likert type scales, ranging from 1 being "very low" to 7 indicating "very high". We employed dichotomous variables $(0=$ "no", $1=$ "yes") to determine the explicit mission of the technology transfer (patent policy), the support from the EXIST programme and the existence of a professorship in entrepreneurship.

\subsection{Statistical analyses}

The data analyses consisted of descriptive statistics, Blau's index of heterogeneity, Kendall's tau correlation and Tobit regression analyses. 
We first calculated the degree of heterogeneity in the qualification of UTTO employees using Blau's (1977) index. This measure is a widely used index of heterogeneity when a series of predefined categories is given. The categories were computed using the number of staff in the respective six qualification categories. The higher the resulting score, the greater is the heterogeneity regarding employee qualification.

Thereafter, to preliminarily examine a potential multicollinearity among the independent variables which could jeopardise the interpretation of their influence on the dependent variables in the regression analysis, we computed and analysed a pairwise correlation matrix. For this purpose, we used Kendall's tau correlation coefficients, as they do not require a normal distribution or a linear relation of the variables. Variables that highly correlate to each other and exceed the cut-off value of 0.60 (Ott and Longnecker, 2008) were incorporated in different regression models in order to ensure the statistical robustness of the outcomes. In addition, the variance inflation factor (VIF) was calculated. According to O'Brien (2007), we consider variables with a VIF of 5.0 and above as indicators for a multicollinearity problem.

To test the individual hypotheses and to explore the role of influencing factors, we employed Tobit regression analysis (Tobit model). Based on this type of multivariate statistical analysis, we analysed the relative influence of each independent variable and its level of significance. In this way, the number of spin-offs are related to the several dimensions of parent organisation's transfer potential, the UTTO transfer strategies and characteristics as well as the spin-off support. For the whole estimation process, we applied STATA software.

\section{Findings and discussion}

4.1 Descriptive results

Regarding the dependent variable, the results indicate that on average, 8.7 spin-offs per university were established ( $\mathrm{SD}=10.5)$. It is observable that the standard deviation is greater than the mean. This shows that the number of spin-offs reported by the UTTOs is widely spread, with data points at the extremes. In fact, the maximum number of university spin-offs we registered was 50, the minimum zero.

With respect to the independent variables, Table I illustrates the descriptive outcomes. In absolute terms, the average transfer potential per university is based on 952.6 researchers, slightly more than 13,000 students and an overall budget of nearly 150 million euros in the year 2008. Here again, the standard deviation indicates that the data are relatively widely dispersed among the universities in our sample. The subjectively perceived transfer potential across all UTTOs is somewhat above the arithmetic mean of the seven-point Likert scale.

Concerning the preferred transfer strategies, UTTOs on average ranked the transfer of information and the transfer by joint research as quite important, whereas the transfer of people was found to be less essential. A look at the correlations between the different transfer strategies reveals no significant negative relationship between them. More than two-thirds of the UTTOs studied had an explicit mission for technology transfer; they also clearly tended to involve researchers or inventors in the commercialisation process. The UTTOs in our sample have on average 5.2 full-time staff, but with a high variation among the respondents. This number is similar to the data obtained by studies among UTTOs in the USA (Markman et al., 2005a; Thursby and Thursby, 2002). Almost three out of four institutions received support from the EXIST programme of the German Federal Government, and the existence of a professorship in entrepreneurship was found in less than half of the universities.
University spin-off formation 


\section{JEPP 3,1}

\begin{tabular}{|c|c|c|c|c|c|c|}
\hline Variables & Obs & Mean & $\mathrm{SD}$ & Min & Mdn & Max \\
\hline Spin-offs & 54 & 8.7 & 10.5 & 0 & 3 & 50 \\
\hline \multicolumn{7}{|l|}{ Transfer potential } \\
\hline Number of researchers & 53 & 952.6 & 933.6 & 52 & 627 & 3,400 \\
\hline Number of students & 54 & 13,064 & 10,941 & 1,600 & 9,382 & 45,539 \\
\hline Budget (in thousand Euro) & 47 & 149,979 & 182,759 & 6,404 & 80,000 & 859,000 \\
\hline Self-reported transfer potential ${ }^{\mathrm{a}}$ & 54 & 4.8 & 1.3 & 2 & 5 & 7 \\
\hline \multicolumn{7}{|l|}{ UTTO transfer strategies $^{\mathrm{a}}$} \\
\hline Transfer of information & 53 & 6.0 & 1.2 & 2 & 5 & 7 \\
\hline Transfer of people & 53 & 3.8 & 1.7 & 1 & 5 & 7 \\
\hline Transfer by joint research & 53 & 6.1 & 1.4 & 2 & 5 & 7 \\
\hline Transfer by patents & 53 & 4.8 & 2.0 & 1 & 5 & 7 \\
\hline Transfer by spin-offs & 53 & 4.7 & 2.0 & 1 & 5 & 7 \\
\hline \multicolumn{7}{|l|}{ UTTO's characteristics } \\
\hline Explicit technology transfer mission ${ }^{\mathrm{b}}$ & 53 & 0.7 & 0.5 & 0 & 1 & 1 \\
\hline Number of UTTO employees & 52 & 5.2 & 4.3 & 0.2 & 4 & 18 \\
\hline Heterogeneity of UTTO employees ${ }^{c}$ & 51 & 0.5 & 0.3 & 0 & 0.6 & 0.8 \\
\hline Involvement of researchers/inventors ${ }^{\mathrm{a}}$ & 53 & 5.5 & 1.3 & 1 & 5 & 7 \\
\hline \multicolumn{7}{|l|}{ Spin-off support ${ }^{b}$} \\
\hline Support from EXIST programme & 54 & 0.7 & 0.4 & 0 & 1 & 1 \\
\hline Professorship in entrepreneurship & 54 & 0.4 & 0.5 & 0 & 0 & 1 \\
\hline
\end{tabular}

Table I.

Descriptive results
Notes: 'Seven-point Likert type scales, ranging from 1 being 'very low' to 7 'very high'; 'dichotomous with 0 representing 'no' and 1 'yes'; 'Blau's index

\subsection{Explorative results}

The correlation matrix in Table II shows results of the bivariate data analysis. It indicates Kendall's tau correlation coefficients and their significance at the 5 per cent level. Accordingly, the number of spin-offs correlates with a series of factors like the number of researchers and students and the university's budget. Other significant linkages were found with the number of UTTO employees and their heterogeneity in qualification. Furthermore, the bivariate analysis revealed a statistically robust correlation between the number of spin-offs and the support received from the EXIST programme.

Given that the number of researchers and students as well as the university's budget are significantly multicollinear with correlation coefficients above 0.75 , we computed three different regression models, keeping one of these variables in each of them. Consequently, Model 1 uses the number of researchers and drops the number of students and the budget. Alternatively, Model 2 keeps the number of students and Model 3 the university's budget as independent variables, while omitting the other two variables, respectively. For each of these models, the respective VIFs are below 5.0, which indicates no multicollinearity problems within the three models.

Having said this, Table III illustrates the results of the three Tobit regression analyses, using the number of spin-offs as the dependent variable. At a first glance, it is remarkable that the heterogeneity of UTTO employees and the participation in the EXIST programme maintained their significant relationship with the number of spinoff firms detected in the bivariate analysis. However, the number of UTTO employees is no longer statistically significant in Model 3, so that this factor is rather a weak predictor for spin-off formation. This is due to its interdependency with the level of heterogeneity of UTTO employees, whose correlation coefficient is close though not superior to the multicollinearity cut-off value of 0.60 . 


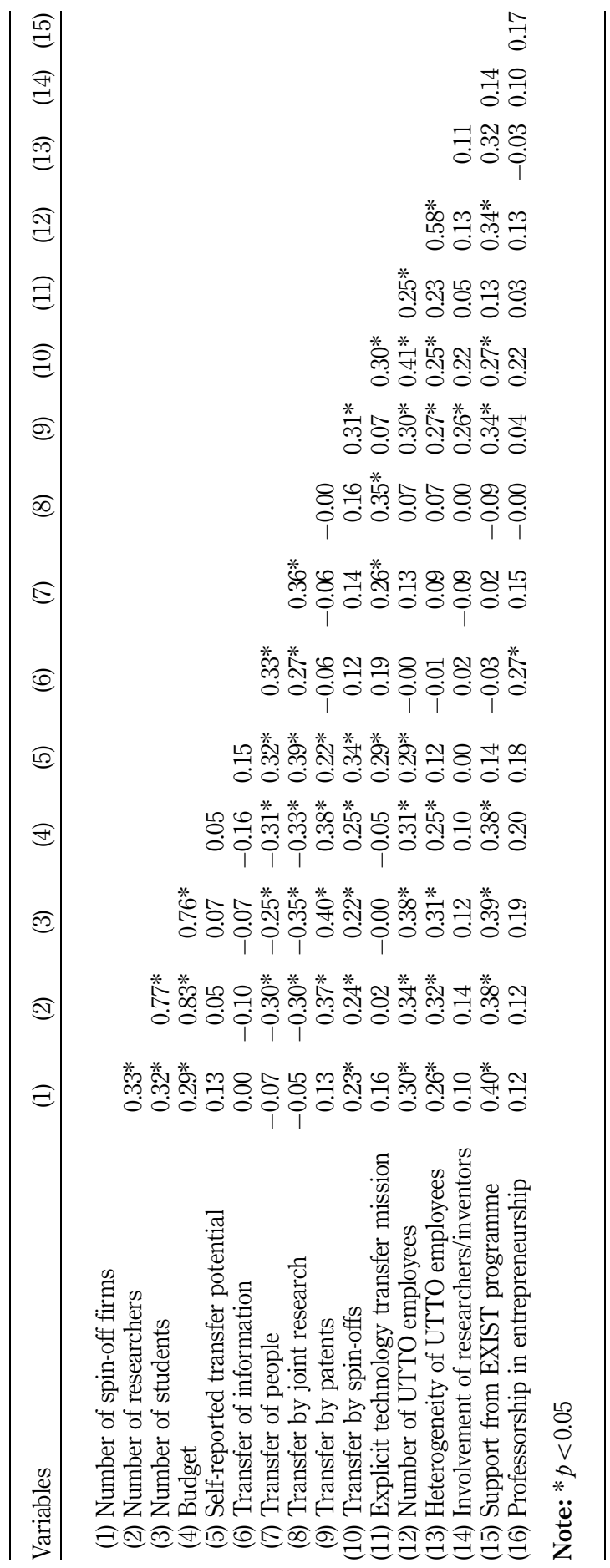

University spin-off formation

169

Table II.

Kendall's Tau correlation matrix 
JEPP

3,1

Table III.

Results of the Tobit regression analyses
Tobit regression models

Coefficients (z-scores)

Model 1

Model 2

Model 3

Transfer potential

Number of researchers $\quad 0.001(0.47)$

Number of students

Budget

Self-reported transfer potential ${ }^{\mathrm{a}}$

UTTO transfer strategies ${ }^{\mathrm{a}}$

Transfer of information

Transfer of people

Transfer by joint research

Transfer by patents

Transfer by spin-offs

UTTO's characteristics

Explicit technology transfer mission ${ }^{\mathrm{b}}$

Number of UTTO employees

Heterogeneity of UTTO employees ${ }^{c}$

Involvement of researchers/inventors ${ }^{a}$

Spin-off support ${ }^{\mathrm{b}}$

Support from EXIST programme

Professorship in entrepreneurship

Number of observations

LR $\chi^{2}(13)$

Prob $>\chi^{2}$

Pseudo $R^{2}$

$\begin{array}{ccc}0.001(0.47) & 0.0005(1.73) & \\ & & 0.000(0.17) \\ 2.396(1.33) & 2.589(1.48) & 3.213(1.66) \\ & & \\ -0.812(-0.39) & -1.992(-1.08) & -1.089(-0.56) \\ -0.482(-0.33) & 0.6121(0.44) & -1.156(-0.85) \\ 0.298(0.17) & 0.410(0.25) & 0.670(0.38) \\ -1.156(-1.01) & -1.888(-1.61) & -0.289(-0.24) \\ -0.228(-0.19) & -0.340(-0.35) & -1.445(-1.07) \\ -1.233(-0.27) & -2.793(-0.64) & -4.440(-0.90) \\ -1.031 *(-1.81) & -1.298^{*}(-2.96) & -0.971(-1.68) \\ 26.039 * *(2.85) & 25.385^{* *}(2.96) & 27.164 * *(2.87) \\ 1.417(0.84) & 1.910(1.15) & 0.819(0.43) \\ & & \\ 10.397 *(2.27) & 10.131^{*}(2.32) & 11.169 *(2.04) \\ 3.024(0.71) & 1.308(0.32) & 6.562(1.52) \\ 47 & 48 & 42 \\ 19.16 & 22.95 & 19.52 \\ 0.1181 & 0.0423 & 0.1078 \\ 0.0613 & 0.0716 & 0.0681\end{array}$

Notes: "Seven-point Likert type scales, ranging from 1 being very "low" to 7 "very high"; b dichotomous with 0 representing "no" and 1 "yes"; 'Blau's index. * $p<0.05$; ** $p<0.01$

Concerning hypotheses testing, our $H 1 a, H 1 b$ and $H 1 c$ must be rejected as the transfer potential of a university, measured by the number of students and researchers as well as by its budget, does present a significant relationship with the number of university spin-off firms. Hypothesis $H 1 d$ must also be refused, as no statistical evidence could be found to support the fact that there is any connection between the UTTOs' self-reported transfer potential and the creation of spin-off firms.

Likewise, the $H 2 a, H 2 b, H 2 c, H 2 d$ and $H 2 e$ cannot be confirmed: a UTTO's focus on the transfer of information and people as well as the transfer by joint research, patents and spin-offs is not significantly linked with spin-off formation. This insight is in line with Van Looy et al. (2011) insofar as we did also not found any trade-offs between the different transfer mechanisms, in particular with spin-off activities. Hence, the empirical evidence on the mutual influence of the different transfer strategies does not indicate that they stand in conflict with each other. Surprisingly, as hypothesised by our $\mathrm{H} 2 e$, in the multivariate data analyses we did not detect any correlation between the number of spin-offs and the declared preference for these firms as an important transfer strategy.

Next, our $H 3 a$ must be rejected, as there was no relationship between spin-off emergence and an explicit mission for technology transfer. Despite the existence of a patent policy was usually proven to be beneficial for technology transfer (Friedman and Silberman, 2003; Mowery et al., 2004), their meaning appears to be reduced for spin-off activities. However, specific university regulations on spin-offs would probably 
have a greater significance, as Caldera and Debande (2010) found. Our $H 3 b$ is partially confirmed, because the number of UTTO employees is linked with spin-off activities in the Models 1 and 2. Despite the rather weak statistical robustness of this outcome, it confirms similar findings made by Caldera and Debande (2010).

Interestingly, there is empirical evidence on a nexus between the heterogeneity regarding the qualification of UTTO employees and the number of spin-offs. Thus, $H 3 \mathrm{c}$ cannot be rejected. In fact, to promote spin-offs effectively, a variety of qualifications and competencies is needed, and heterogeneously staffed UTTO are supposed to do this better. Again, $H 3 d$ must be refused, since spin-off formation and the involvement of researchers/inventors in the commercialisation process were not significantly related.

The participation in the EXIST programme is linked with university spin-off formation, which confirms our H4a. For Spain, Caldera and Debande (2010) made analogous observations, as in their sample the existence of spin-off programmes was also positively linked with entrepreneurial activities. At a first glance, it seems that the EXIST programme can be an effective measure to increase the number of spin-offs. However, causality must cautiously be deducted, as there could also be the possibility that having more spin-offs increases the chances for a university to get funding from the EXIST programme. Finally, our sample showed no direct relationship between the existence of a university professorship in entrepreneurship and the level of spin-off activities. Hence, our $H 4 b$ has to be rejected.

\section{Conclusions and limitations}

The objective of this paper was to investigate contingency factors being potentially related with university spin-off emergence. To this end, we analysed 54 UTTOs in Germany, a population which to date lack scientific scrutiny. We advanced previous studies on antecedents of spin-off formation not only in geographical terms; we also included some underexplored and new elements in the analysis. We anchored our research in institutional and resource-based theories and identified specific institutional and organisational factors as important determinants of the number of spin-offs emanating from a university. We found out that a high degree of heterogeneity in the qualification of UTTO employees as well as the funding and support received from the EXIST programme are highly relevant contingency factors for spin-off formation. In addition, we also revealed that different UTTO transfer strategies do not counteract the formation of spin-offs. These insights allow us to draw several theoretical and practical implications, not only for public policy researchers and makers, but also for entrepreneurship scholars and practitioners.

Considering our research outcomes, we must take into account that, in Germany, UTTOs play and fulfil an essential role when it comes to promoting the creation of university spin-offs. In accordance with Markman et al. (2005b), and still focusing on Germany, we could confirm that UTTOs adopt certain measures and configurations that correlate with the emergence of spin-offs. In this way, UTTOs can be interpreted as catalysts of new venture formation and regional development. However, we also uncovered a high range of fluctuation in the number of spin-offs created from the universities subject to our research. Consequently, it seems that there is still a lack of consensus with respect to the importance of spin-offs as an effective channel to transform research results into economic value. In line with Harrison and Leitch (2010), it seems that creating spin-offs is only one out of a multiplicity of knowledge and technology transfer activities UTTOs adopt. Interestingly, the descriptive data we
University spin-off formation 
JEPP

3,1

172 obtained show that the UTTOs on average ranked the transfer of information and the transfer by joint research as most important, implying a lower attention to spin-off formation as transfer strategy.

At institutional level, we analysed whether these different transfer strategies are in conflict with spin-off formation and found no trade-offs between them. With this, we were able to confirm the hitherto existing few empirical evidence (Crespi et al., 2011; Van Looy et al., 2011). In other words, pursuing different or multiple transfer objectives will not be detrimental to the establishment of spin-offs. Interestingly, those UTTOs attributing preference to spin-off formation as a transfer strategy were not more effective in doing so. This permits the conclusion that universities aiming at the promotion of spin-offs need appropriate patent policies and regulations which do not jeopardise the usage of research outcomes for entrepreneurial purposes. The fact that approximately one-third of the surveyed universities had no technology transfer mission at all underpins the necessity for explicit regulatory measures.

From a resource-based perspective, our research approves the importance of UTTO staffing (Siegel et al., 2004). The particular contribution of our study, however, goes beyond the mere number of UTTO employees as a contingency factor; it rather reveals that their heterogeneity in qualifications is related to the emergence of spin-offs. In fact, spin-off assistance and support requires a set of sometimes quit different competencies and skills, so that a broader qualification background of UTTO staff indeed is likely to be an antecedent of entrepreneurial activities within the academia. This new variable should be addressed by further studies, above all with regard to what particular qualifications of UTTO staff do enhance the effectiveness of transfer activities.

Additionally, we found empirical evidence for the importance of support programmes to promote spin-off activities. In this way, we confirmed similar findings of Caldera and Debande (2010) in Spain. In a German context, when attempting to commercialise research results by establishing spin-off firms, the EXIST programme can be considered a powerful tool to promote these efforts. Those universities that participated or still participate in the EXIST programme exhibit a significantly higher number of spin-offs. However, there was no specific organisational endowment (e.g. UTTOs, professorships in entrepreneurship) that showed any unique influence concerning the facilitation of spin-off activities. Accordingly, when spin-off promotion is intended, isolated initiatives are ineffective. In this regard, a holistic concept should be promoted in order to integrate both scientific and administrative areas within the university.

Finally, our study does have some limitations which should be taken into consideration. The applied research design limits our sample to German higher education institutions and their UTTOs. Thus, generalisations should be made cautiously. As we used cross-sectional data and analysed relationships between spin-off emergence and institutional and organisational factors, causality has to be deducted carefully. Furthermore, other possible contingency factors on the formation of spin-offs were not included in our study. The most relevant include the individual entrepreneurial intentions of students and researchers as well as the general acceptance and perception of academic entrepreneurship on the university level. Thus, further research and thorough scrutiny is necessary. We also did not take environmental factors such as promotional programmes for spin-offs at state or regional level into consideration. The same applies to general economic conditions and climates that favour the emergence of new ventures. Another limitation can be seen in the concentration of our research on the quantity and not on the quality of spin-offs. The mere consideration of quantitative outcomes has, however, only a limited validity. Nonetheless, our study sets a cornerstone in the investigation of UTTOs 
and university spin-offs in Germany, and the conjunction of our and further works surely will allow valuable comparisons and insights.

\section{References}

Arundel, A. and Bordoy, C. (2008), Developing Internationally Comparable Indicators for the Commercialization of Publicly-Funded Research, Working Paper Series No. 2008-075, UNU-MERIT, United Nations University, Maastricht.

Bekkers, R. and Bodas Freitas, I.M. (2008), "Analysing knowledge transfer channels between universities and industry: to what degree do sectors also matter?", Research Policy, Vol. 37 No. 10, pp. 1837-1853.

Belenzon, S. and Schankerman, M. (2009), "University knowledge transfer: private ownership, incentives, and local development objectives", Journal of Law and Economics, Vol. 52 No. 1, pp. 111-144.

Bercovitz, J. and Feldman, M. (2005), "Entrepreneurial universities and technology transfer: a conceptual framework for understanding knowledge-based economic development", The Journal of Technology Transfer, Vol. 31 No. 1, pp. 175-188.

Blau, P. (1977), Inequality and Heterogeneity - A Primitive Theory of Social Structure, Free Press, New York, NY.

Bramwell, A. and Wolfe, D.A. (2008), "Universities and regional economic development: the entrepreneurial university of Waterloo", Research Policy, Vol. 37 No. 8, pp. 1175-1187.

Caldera, A. and Debande, O. (2010), "Performance of Spanish universities in technology transfer: an empirical analysis", Research Policy Vol. 39 No. 9, pp. 1160-1173.

Charles, D. (2003), "Universities and territorial development: reshaping the regional role of UK Universities", Local Economv: The Iournal of the Local Economv Policy Unit, Vol. 18 No. 1, pp. 7-20.

Chrisman, J.J., Hynes, T. and Fraser, S. (1995), "Faculty entrepreneurship and economic development: the case of the University of Calgary", Lournal of Business Venturing, Vol. 10 No. 4, pp. 267-281.

Cohen, W.M., Nelson, R.R. and Walsh, J.P. (2002), "Links and impacts: the influence of public research on industrial R\&D”, Management Science, Vol. 48 No. 1, pp. 1-23.

Crespi, G., D'Este, P., Fontana, R. and Geuna, A. (2011), "The impact of academic patenting on university research and its transfer", Research Policy, Vol. 40 No. 1, pp. 55-68.

Debackere, K. and Veugelers, R. (2005), "The role of academic technology transfer organizations in improving industry science links", Research Policv, Vol. 34 No. 3, pp. 321-342.

D'Este, P. and Fontana, R. (2007), "What drives the emergence of entrepreneurial academics? A study on collaborative research partnerships in the UK", Research Evaluation, Vol. 16 No. 4, pp. 257-270.

D'Este, P. and Patel, P. (2007), "University-industry linkages in the UK: what are the factors underlying the variety of interactions with industry?", Research Policv, Vol. 36 No. 9, pp. 1295-1313.

Di Gregorio, D. and Shane, S.A. (2003), "Why do some universities generate more start-ups than others?”, Research Policv, Vol. 32 No. 2, pp. 209-227.

Druilhe, C. and Garnsey, E. (2004), "Do academic spin-outs differ and does it matter?", The Iournal of Technology Transfer, Vol. 29 Nos 3/4, pp. 269-285.

FGF (2012), Entrepreneurship-Professuren an Öffentlichen und privaten Hochschulen in Deutschland, Förderkreis Gründungs-Forschung e. V., Bonn.

Friedman, J. and Silberman, J. (2003), "University technology transfer: do incentives, management, and location matter?", The Iournal of Technology Transfer. Vol. 28 No. 1, pp. 17-30.
University spin-off formation 
JEPP 3,1
Grant, R.M. (1991), “The resource-based theory of competitive advantage: implications for strategy formulation", California Management Review, Vol. 33 No. 3, pp. 114-135.

Harrison, R.T. and Leitch, C. (2010), "Voodoo institution or entrepreneurial university? Spin-off companies, the entrepreneurial system and regional development in the UK", Regional Studies, Vol. 44 No. 9, pp. 1241-1262.

Heirman, A. and Clarysse, B. (2004), "How and why do research-based start-ups differ at founding? A resource-based configurational perspective", The Iournal of Technology Transfer, Vol. 29 Nos 3/4, pp. 247-268.

Hsu, D.H., Roberts, E.B. and Eesley, C.E. (2007), "Entrepreneurs from technology-based universities: evidence from MIT", Research Policv, Vol. 36 No. 5, pp. 768-788.

Jensen, R. and Thursby, M.C. (2001), "Proofs and prototypes for sale: the licensing of university inventions", The American Economic Review, Vol. 91 No. 1, pp. 240-259.

Katz, J.A. (2003), "The chronology and intellectual trajectory of American entrepreneurship education: 1876-1999", Journal of Business Venturing, Vol. 18 No. 2, pp. 283-300.

Kenney, M. and Goe, W.R. (2004), "The role of social embeddedness in professorial entrepreneurship: a comparison of electrical engineering and computer science at UC Berkeley and Stanford", Research Policv, Vol. 33 No. 5, pp. 691-707.

Kulicke, M. (2006), EXIST - Existenzgründungen aus Hochschulen: Bericht der wissenschaftlichen Begleitung zum Förderzeitraum 1998 bis 2005, IRB Verlag, Stuttgart.

Lach, S. and Schankerman, M. (2008), "Incentives and invention in universities", The RAND Journal of Economics, Vol. 39 No. 2, pp. 403-433.

Lockett, A. and Wright, M. (2005), "Resources, capabilities, risk capital and the creation of university spin-out companies", Research Policy, Vol. 34 No. 7, pp. 1043-1057.

Mahoney, J.T. and Pandian, J.R. (1992), "The resource-based view within the conversation of strategic management”, Strategic Management Journal, Vol. 13 No. 5, pp. 363-380.

Markman, G.D., Siegel, D.S. and Wright, M. (2008), "Research and technology commercialization", Journal of Management Studies, Vol. 45 No. 8, pp. 1401-1423.

Markman, G.D., Gianiodis, P.T., Phan, P.H. and Balkin, D.B. (2005a), "Innovation speed: transferring university technology to market”, Research Policy Vol. 34 No. 7, pp. 1058-1075.

Markman, G.D., Phan, P.H., Balkin, D.B. and Gianiodis, P.T. (2005b), "Entrepreneurship and universitybased technology transfer", Journal of Business Venturing, Vol. 20 No. 2, pp. 241-263.

Moray, N. and Clarysse, B. (2005), "Institutional change and resource endowments to sciencebased entrepreneurial firms", Research Policy, Vol. 34 No. 7, pp. 1010-1027.

Mowery, D.C., Nelson, R.R., Sampat, B.N. and Ziedonis, A.A. (2004), Ivory Tower and Industrial Innovation: University-Industry Technology Transfer Before and After the Bayh-Dole Act, Stanford Business Books, Palo Alto, CA.

Ndonzuau, F.N., Pirnay, F. and Surlemont, B. (2002), "A stage model of academic spin-off creation”, Technovation, Vol. 22 No. 5, pp. 281-289.

North, D.C. (1990), Institutions, Institutional Change and Economic Performance, Cambridge University Press, Cambridge.

North, D.C. (1994), "Economic performance through time", American Economic Review, Vol. 84 No. 3, pp. 359-368.

O'Brien, R.M. (2007), “A caution regarding rules of thumb for variance inflation factors”, Quality Quantity, Vol. 41 No. 5, pp. 673-690.

OECD (2002), Benchmarking Industry-Science Relationships, OECD Publishing, Paris.

O'Shea, R.P., Allen, T.J., Chevalier, A. and Roche, F. (2005), "Entrepreneurial orientation, technology transfer and spinoff performance of US universities", Research Policy. Vol. 34 No. 7, pp. 994-1009. 
Ott, R.L. and Longnecker, M.T. (2008), An Introduction to Statistical Methods and Data Analysis, 6th ed., Duxbury Press, Pacific Grove, CA.

Penrose, E. (1959), The Theory of the Growth of the Firm, Blackwell, Oxford.

Pérez Pérez, M. and Martínez Sánchez, A. (2003), "The development of university spin-offs: early dynamics of technology transfer and networking”, Technovation, Vol. 23 No. 10, pp. 823-831.

Pirnay, F., Surlemont, B. and Nlemvo, F. (2003), "Toward a typology of university spin-offs", Small Business Economics, Vol. 21 No. 4, pp. 355-369.

Powers, J.B. and McDougall, P.P. (2005), "University start-up formation and technology licensing with firms that go public: a resource-based view of academic entrepreneurship", Lournal of Business Venturing, Vol. 20 No. 3, pp. 291-311.

Rasmussen, E. (2008), "Government instruments to support the commercialization of university research: lessons from Canada”, Technovation, Vol. 28 No. 8, pp. 506-517.

Rasmussen, E. (2011), "Understanding academic entrepreneurship: exploring the emergence of university spin-off ventures using process theories,", International Small Business Iournal, Vol. 29 No. 5, pp. 448-471.

Rasmussen, E. and Borch, O.J. (2010), "University capabilities in facilitating entrepreneurship: a longitudinal study of spin-off ventures at mid-range universities", Research Policy, Vol. 39 No. 5, pp. 602-612.

Rogers, E.M., Yin, J. and Hoffmann, J. (2000), "Assessing the effectiveness of technology transfer offices at US research universities", The Journal of the Association of University Technology Managers, Vol.12, pp. 47-80, available at: www.autm.net/AUTM_Journal_Volume_XII_2000/ 9741.htm

Rosenberg, N. and Nelson, R.R. (1994), "American universities and technical advance in industry”, Research Policv, Vol. 23 No. 3, pp. 323-348.

Rynes, S.L., Bartunek, J.M. and Daft, R.L. (2001), "Across the great divide: knowledge creation and transfer between practitioners and academics", Academy of Management Iournal, Vol. 44 No. 2, pp. 340-355.

Shane, S.A. (2004), Academic Entrepreneurship: University Spinoffs and Wealth Creation, Edward Elgar Pub, Aldershot.

Siegel, D.S., Waldman, D.A., Atwater, L.E. and Link, A.N. (2004), "Toward a model of the effective transfer of scientific knowledge from academicians to practitioners: qualitative evidence from the commercialization of university technologies", Iournal of Engineering and Technology Management, Vol. 21 Nos 1/2, pp. 115-142.

Thursby, J.G. and Thursby, M.C. (2002), "Who is selling the Ivory Tower? Sources of growth in university licensing”, Management Science, Vol. 48 No. 1, pp. 90-104.

Valentín, E.M.M. (2002), "A theoretical review of co-operative relationships between firms and universities", Science and Public Policy, Vol. 29 No. 1, pp. 37-46.

Van Looy, B., Landoni, P., Callaert, J., Van Pottelsberghe, B., Sapsalis, E. and Debackere, K. (2011), "Entrepreneurial effectiveness of European universities: an empirical assessment of antecedents and trade-offs", Research Policy, Vol. 40 No. 4, pp. 553-564.

Vohora, A., Wright, M. and Lockett, A. (2004), "Critical junctures in the development of university high-tech spinout companies”, Research Policy Vol. 33 No. 1, pp. 147-175.

Wernerfelt, B. (1984), “A resource-based view of the firm”, Strategic Management Iournal, Vol. 5 No. 2, pp. 171-180.

Wright, M., Clarysse, B., Lockett, A. and Knockaert, M. (2008), "Mid-range universities' linkages with industry: knowledge types and the role of intermediaries", Research Policy, Vol. 37 No. 8, pp. 1205-1223. 
JEPP

3,1

\section{6}

\section{About the authors}

Arndt Lautenschläger is an Assistant Professor of Entrepreneurship at the Department of Business Administration, University of Applied Sciences Jena, Germany. He studied economics at the Friedrich-Schiller-University in Jena. Currently he is involved in several projects on knowledge-based start-ups from the academic sector. He is a member of the Center for Innovation and Entrepreneurship. His research interests are university-based start-ups, entrepreneurship education, success-related factors of business start-ups and international entrepreneurship.

Heiko Haase is a Full Professor of Entrepreneurship and Innovation Management at the Department of Business Administration, University of Applied Sciences Jena, Germany. He studied industrial engineering and received his $\mathrm{PhD}$ in economic sciences from the Ilmenau University of Technology in 2003. His research fields comprise entrepreneurship, small and medium-sized enterprises, innovation management, technology transfer and intellectual property. He is the Director of the Center for Innovation and Entrepreneurship at the University of Applied Sciences Jena. Professor Heiko Haase is the corresponding author and can be contacted at: heiko.haase@ fh-jena.de

Jan Kratzer is a Full Professor for Entrepreneurship and Innovation Management and Director of the Center for Entrepreneurship at the Berlin University of Technology (TU Berlin). His research focuses mainly on the communication patterns within new product development teams and projects, the development of social network measures, open innovation networks and the embeddedness of marketing roles in social networks. His work has appeared in a number of leading journals, including Journal of Product Innovation Management, Research Policy, Journal of Consumer Research and Creativity and Innovation Management.

To purchase reprints of this article please e-mail: reprints@emeraldinsight.com Or visit our web site for further details: www.emeraldinsight.com/reprints 
This article has been cited by:

1. SinellAnna, Anna Sinell, IffländerVivien, Vivien Iffländer, MuschnerAntonia, Antonia Muschner. Uncovering transfer - a cross-national comparative analysis. European Journal of Innovation Management, ahead of print. [Abstract] [Full Text] [PDF]

2. Pinaki Nandan Pattnaik, Satyendra C. Pandey. 2016. Revisiting University Spinoffs: Conceptual Advancements and Theoretical Underpinnings. International Journal of Innovation and Technology Management 13:01, 1650005. [Crossref] 